DIGITAL COMMONS
@ UNIVERSITY OF SOUTH FLORIDA

Journal of African Conflicts and

Peace Studies

January 2021

\title{
Women, Peace and Security in Zimbabwe - The Case of Conflict in Non War Zones
}

\author{
Rutendo Chabikwa \\ University of Oxford, chabikwarutendo@gmail.com
}

Follow this and additional works at: https://digitalcommons.usf.edu/jacaps

Part of the Africana Studies Commons, Other Feminist, Gender, and Sexuality Studies Commons, and the Race, Ethnicity and Post-Colonial Studies Commons

\section{Recommended Citation}

Chabikwa, Rutendo (2021) "Women, Peace and Security in Zimbabwe - The Case of Conflict in Non War Zones," Journal of African Conflicts and Peace Studies: Vol. 4: Iss. 2, .

DOI: https://doi.org/10.5038/2325-484X.4.2.1141

Available at: https://digitalcommons.usf.edu/jacaps/vol4/iss2/3

This Article is brought to you for free and open access by the Open Access Journals at Digital Commons @ University of South Florida. It has been accepted for inclusion in Journal of African Conflicts and Peace Studies by an authorized editor of Digital Commons @ University of South Florida. For more information, please contact digitalcommons@usf.edu. 


\section{Women, Peace and Security in Zimbabwe - The Case of Conflict in Non War}

Zones

\section{Cover Page Footnote}

I acknowledge Dr. Keina Yoshida and Dr. Aisling Swaine for their assistance, comments, and support. 


\section{Introduction}

Conflict settings leave numerous people in vulnerable circumstances. In the aftermath of crucial events of the late $20^{\text {th }}$ century, including the civil wars in Bosnia, the armed conflict in the Democratic Republic of Congo, and the genocide in Rwanda; the UN Security Council adopted Resolution 1325 (UNSCR 1325) on Women, Peace and Security (WPS) in 2000. It was the first resolution in a group of nine total resolutions that are part of what is generally known as the WPS agenda. The agenda is seen as having dramatic and "transformative potential - the potential to escape cycles of conflict, to create inclusive and more democratic peace-making and to turn from gender inequality to gender justice" (Peace Women 2014). It is heralded as a major advancement in understanding and responding to armed conflict in a gendered manner and accounting for the gender disparate experiences of individuals during and after conflict. The initial resolution was widely regarded as ground-breaking, particularly because the experiences of women and girls were finally foregrounded (Cabrera-Balleza 2011, 16). Later resolutions; 1820 (2009); 1888 (2009); 1889 (2010); 1960 (2011); 2106 (2013); 2122 (2013); 2242 (2015), and 2467 (2019); were added to become part of the WPS agenda, looking at more specific aspects of armed conflict and the violence experienced by women and girls.

These documents that make up the WPS agenda seek to address current conflict and prevent future conflict. Miller and others describe that UNSCR 1325, "recognizes that women and girls are particularly affected in situations of crisis and armed conflict and declares that their participation at all levels of prevention, resolution, reconstruction, and peacekeeping of conflicts is essential to achieving sustained peace and security"(Miller, Pournik, and Swaine 2014, 6). Conflict is the centre of this agenda. The WPS agenda is thus not simply a reactive one, but one that aims at being proactive in preventing future conflict. Although the WPS agenda was a breakthrough for civil society organisations and other parties involved, weaknesses and gaps still remain. Work by Ní Aoláin( 2016) and Frazer (2010) has highlighted deficiencies in the WPS declarations, while Smith (2020)and Haastrup(2018) have critiqued some operational aspects of the of the WPS agenda.

While conflict, especially armed conflict, is the point of departure for the WPS agenda, there is a very narrow understanding of the term within the agenda thereby minimising its transformative potential. The documents are not legally binding, that is they do not stipulate that a nation puts them into law, they offer recommendations on how the agenda can be operationalised, particularly through National Action Plans (NAPs). This means that the agenda has practical and programmatic impact for the different nations that sign onto it. In an attempt to highlight women's experiences of conflict, the WPS agenda frames armed conflict in a narrowly gendered way and only as it manifests itself in extreme war scenarios. Armed conflict can exist in non-war contexts, and it is pertinent that communities in those contexts be offered the same protection and attention proffered in the WPS agenda. This narrow perspective of conflict has the effect of narrowing down the examples of countries that are considered to be in conflict and side-lining other instances in which women, children, girls, and othered men, are unsafe thereby limiting the transformative potential of the WPS agenda to create gender justice in societies. The result of this narrowed understanding of conflict is that some contexts of conflict are ignored. This is seen in the fact that to date, only 84 countries have adopted a National Action Plan in support of UNSCR 1325 and some countries focus on how they intervene in external conflict (Women's International League for Peace and Freedom 2014).

Zimbabwe does not have a NAP to operationalise the WPS agenda. Zimbabwe exemplifies those nations that make complex the understanding of conflict. not that it does not need a NAP, it is simply because, as will be argued and illustrated, in recent history Zimbabwe has existed in a space in which conflict as understood by the WPS agenda does not apply. Therefore, lobbying for a WPS NAP can be challenging. This paper answers the question: How does the case of Zimbabwe as a non-war zone exemplify the need for a broader understanding of conflict in the WPS agenda? 
The paper will briefly look at the ways in which the various WPS documents frame armed conflict then at the literature from which the term 'non war zone' is drawn to pull out characteristics of non-war zones as well as to expand on the traits of these zones. It will then detail the theoretical framework in which the analysis is grounded, which draws from feminist International Relations (IR) theory as well as postcolonial theory to further contextualise Zimbabwe. Through this methodology and conceptual framework, the paper will look at Zimbabwe's most recent history, arguing that the case of Zimbabwe as a non-war zone exemplifies the need for a broader understanding of conflict for one main reason; armed conflict is engrained in how the Zimbabwean state interacts with civilians. Throughout the agenda there is mention of "parties to conflict", but armed conflict does not always occur between two armed parties as Zimbabwe shows. Without broadening the understanding of conflict, women's experiences and those of vulnerable men too, are left in a liminal space and limit the potential for escaping cycles of conflict and preventing full on war.

\section{Literature Review}

As Miller and others observe, the WPS framework was drafted with explicit attention to gendered violence occurring in armed conflict events such as the systematic gender violence in Bosnia, Rwanda, and the DRC provided an important historical catalyst to the framework (Miller, Pournik, and Swaine 2014). However, this historical point of departure proves less useful in contexts that deviate from that situation.

To refer to these contexts, I adopt the term 'non war zones', as coined by Santos and others in an essay that applies a gendered lens to the UNSCR 1325 (Santos, Moura, and Roque 2010). They argue that crucial problems with 1325 arise as "products of the concepts of gender, violence, [and] security that inform the Resolution"(4). They write that, "By non-war zones or formal peace scenarios we mean contexts characterised by growing levels of gun violence perpetrated by civilians and/or state agents at an increasingly micro sphere"(5). This can be organised or unorganised violence. Santos and others further argue that resolution 1325, the cornerstone of the WPS agenda, does not cater to armed violence in non-war zones. They hold that non war zones are global phenomena, reflecting aspects of structural "militarisation, gender ideologies and social exclusion"(2). Moura and Roque (2009) further this understanding of non-war zones by looking at how this type of conflict exists in urban areas. In their analysis, focused on Brazil and El Salvador, Moura and Roque describe this non war zone phenomenon as a "macro level sort of violent conflict" (73). These contexts "cannot be accurately described as either war or peace" (73). In their case-study, the main victims and perpetrators of this violence are socially marginalised young men.

The observation of Santos, Moura, and Roque is pertinent and expands armed conflict by looking at gun violence. This draws from "new war" zones, articulated by Chinkin and Kaldor (2013). Chinkin and Kaldor differentiate "new wars" from "old wars" in that, "old wars tend to be extreme in the sense of maximizing and totalizing violence, while new wars tend to be persistent and more difficult to end" (169). In their analysis of non-war zones, Moura and Roque expand on the concept using the term 'newest wars' which occur in nonwar zones (2009). According to Moura and Roque, newest wars is "the dissemination of armed violence at an increasingly micro scale, whose privileged scenarios are urban centres of countries living in formal peace" (Moura and Roque 2009, 74). This understanding expands how non war zone conflict is still armed conflict. One shortcoming, however, of Santos and others' contribution is the focus on urban areas. In so doing, some demographics affected by armed conflict or gun violence are ignored.

Various scholars identify, albeit using different terms, the characteristics of non-war zones. For example, Scheper-Hughes (1997) identifies the centrality of 'everyday violence' which "encompass the implicit, legitimate, organised, and routinised violence of particular social-political state formations"(471). This closely parallels Santos and others' focus on hyper concentration of daily violent acts, in which violence, and consequently conflict, is masked because it is normalized and considered part of everyday existence. Scheper-Hughes argues that this violence, "is [often] 'mis-recognised' because its very familiarity renders it invisible" 
(1997, 471). Scheper-Hughes extrapolates her analysis of everyday violence to look at how the state can be a perpetrator of that violence and commit "peace-time crimes" (471). While her work precedes the phrase "non war zone" as used by Santos and others, her central observation is that persistent peace-time crimes maintain the status quo since "internal 'stability' is purchased with the currency of peace-time crimes" (473). This is what Santos and others regard as "formal peace" (Santos, Moura, and Roque 2010,10). The above scholars noted consider the idea of non-war zones through different terminology.

\section{Methodology}

This research adopts a pluralist approach using feminist IR theory and postcolonial theory. The WPS agenda that aims to apply gender sensitive analysis to conflict scenarios, is housed in the UN, an international political body. Thus, Feminist IR theory which pays attention to the power relations present at global, state, and societal level engages the agenda fully. True (2010) argues that, "what distinguishes most feminist theories of international relations is their ethical commitments to inclusivity and self-reflexivity, and attentiveness to relational power" (3). An advantage of feminist IR theory is that it is not monolithic and is applicable in conjunction with other epistemological approaches. Feminist IR theorists consciously build, "theory from practice and to guide political practice, but their normative theoretical and political positions are plural" (True 2010, 2). A disadvantage of feminist IR theory, however, is that it supports the feminist movements' need for "a global institutional powerhouse to promote the rights of women and girls worldwide, rather than a system where everyone is responsible for integrating gender perspectives" (True 2010, 16). While the argument in this paper is not based on that belief in a need for an international system, feminist IR theory is essential in analysing international powerhouses such as the UN. This essay does not critique the existence and function of the UN, but rather elements of it. Feminist IR theory allows for analysis within the logic of that system. In order to contextualise Zimbabwe as the site of analysis as well as to see how feminist IR theory can function in that specific context, this research will also draw from postcolonial theory and critical race theory as well.

According to UN Article 24, the UN Security Council has the primary responsibility for the maintenance of international peace and security" (Malone 2008, 117). In the post-cold war era there were, "major shifts in the Council's approach to conflict and its resolutions. Situations held by the Council to constitute threats to international peace expanded to include a coup against a democratically elected regime (in Haiti); a range of humanitarian catastrophes, particularly those generating large exoduses of displaced persons, internally and internationally; and acts of terrorism" (Malone 2008, 121). The WPS agenda, falls within this new understanding of international peace, extending the Council's traditional post-war focus on preventing nuclear war. Since the Council's agenda is to maintain international peace, it focuses on conditions that it considers a threat to peace.

While the WPS agenda, through its nine foundational documents, is centrally concerned with gender violence in conflict, the documents do not offer a strict definition of conflict. It is implied within the language of the agenda. For example, in the most recent UNSCR 2467 (2019) the council states concern "over the slow progress in addressing and eliminating sexual violence in situations of armed conflict" (S/RES/2467 2019) without actually defining armed conflict. UNSCR 1325 (2000) on Women, Peace and Security not only called for the inclusion of women in peacekeeping contexts but also called for the use of a gendered lens in understanding the experiences of women and girls in conflict. Here, there is an assumption that conflict scenarios are only those in which peacekeepers will [need to] be deployed is made. This shortcoming calls for a theoretical framework that also dissects the language in question. I will thus deploy the tools provided by a Feminist Post Structural Discourse Analysis (FPDA).

A weakness of this ground-breaking resolution is that it equates conflict, to war (Santos, Moura, and Roque 2010, 2). With this language, Resolution 1325 not only limits conflict to behaviours synonymous with active war-like conflict, but it further extends the experience and manifestation of conflict in narrow gender binary ways. The resolution expresses "concern that 
civilians, particularly women and children, account for the vast majority of those adversely affected by armed conflict," (S/RES/1325 2000) and negates to mention that othered masculinities too are adversely affected. This resolution fortifies a binary view of conflict, in which women are the victims of physical and extreme forms of violence perpetrated by men. Applying FPDA to the inaugural document of the WPS agenda reveals how the multiplicity of femininities and masculinities is ignored. As Baxter argues, "feminist post-structuralism appreciates the unevenness and ambiguities of power relations between males and females" (Baxter 2003, 32). That unevenness and ambiguity is not present in the Resolutions.

This weakness is not only present in UNSCR 1325, but is also seen in other resolutions, such as UNSCR 1820 (2008) and UNSCR 1888 (2009) where the gender binary nature of conflict is further highlighted by the focus on women experiencing sexual violence as a tactic of war. The resolutions condemn all forms of violence including sexual violence, experienced particularly by women and girls, and makes recommendations to enforce "military disciplinary measures" (S/RES/1888 2009). They also uphold "the principle of command responsibility, training troops on the categorical prohibition of all forms of sexual violence against civilians, debunking myths that fuel sexual violence, vetting armed and security forces to take into account past actions of rape and other forms of sexual violence, and evacuation of women and children under imminent threat of sexual violence to safety" (S/RES/1820 2008). This is a legitimate claim that would benefit from an extension in mentioning the diversity in women, such as the existence of transwomen, and the dangers that othered men face as well. Such a narrow perspective on conflict and how to combat it relegates the creation of conflict to a monolithic version of 'man' and the victimhood to a similarly monolithic version 'woman'. The focus on sexual violence as the essential form of violence experienced by women in conflict, crucial as it is, ignores the potential and reality, that there are other gendered ways in which women and othered men experience conflict, especially in non-war zones. Applying a feminist poststructuralist lens to these phrases, it is clear that this claim solidifies that contexts in which conflict exists are extreme war zones.

UNSCR 1960 (2010) calls on the Secretary General, to provide "detailed information on parties to armed conflict that are credibly suspected of committing or being responsible for acts of rape or other forms of sexual violence". This further limits the understanding of conflict to be a situation in which women experience sexual abuse by ignoring other markers of violence, which may be present prior to sexual violence such as the economic oppression of women, or limited access to justice for women, girls and othered men. In fact, I argue that, sexual violence is the most visible indicator of conflict.

It would be inaccurate, however, to state that the WPS agenda continuously states only that women are victims of sexual violence during conflict. UNSCR 2106 (2013) cites for the first time that men can also be victims of sexual violence in war. However, emphasis for protection of civilians is placed on "establishing protection mechanisms for women and children in cantonment sites," as well as "offering trauma and reintegration support to women and children formerly associated with armed groups, as well as ex-combatants" (S/RES/2106 2013). This idea is similar to UNSCR 2122 (2013) where there is a call to "ensure humanitarian aid and funding includes provision for the full range of medical, legal, psychosocial and livelihood services to women affected by armed conflict and post-conflict situations" (S/RES/2122 2013). Provisions made for the protection of those that suffer in conflict further exemplify the understanding of conflict in the WPS agenda as being restricted to cases of active war violence. The language in the resolutions is important because of what it mentions, women as victims, but the language is also important for what it does not mention: women in non-war conflict scenarios. A feminist post-structuralist approach to the language of the documents reveals that the language itself has real ramifications. When this language is analysed through a feminist post-structuralist lens, it is clear that these realities are not gender or context neutral. 
The gendered binary perspective of conflict is also seen in the UNSCR 1889 (2009). Although its main aim was to advocate for women's participation in post conflict processes, particularly in peacebuilding processes, it further entrenched the notion that women are typically simply victims during conflict but are essential actors in post-conflict scenarios. This not only ignores the potential that women themselves are also actors in the conflict, but seeing them "as actors in addressing and resolving situations of armed conflict," (S/RES/1889 2009) implies that the involvement of women in conflict can be minimised to victimhood during conflict, a status that is erased post-conflict. The lines between conflict and non-conflict are thickened in a gendered way by the focus on conflict as involving large bodies, organisations, militia, or between states. In UNSCR 2242 (2015), major emphasis is put on terrorism and counter-terrorism efforts as well as international mass displacement. Some may argue that this is because the UNSCR's mandate is to maintain international peace and thus a focus on these conflicts signals their threat of international peace. However, as Weedon(1987) argues, one of the contributions of contemporary feminist theory to feminist post-structural discourse analysis is the belief that "the personal is political" (74). By not considering seemingly everyday forms of armed conflict as threats to international peace, the WPS agenda thus becomes faulty. Once again, I argue, that once a conflict reaches macro level, much like with sexual violence that is the height of the conflict and by no means the beginning of it.

It is important to mention here that the WPS agenda while having a limited understanding of conflict, has managed to broaden its picture of post conflict settings. In April 2019, the UNSC added another resolution, Resolution 2467 to the agenda. It strengthens the call for justice and accountability and notes the importance of a survivorcentred approach in post-conflict settings. Beyond that, it looks at justice holistically by considering the effects of issues such as HIV infections, children born of conflict sexual violence, and supporting grassroots organisations and traditional leaders in as potentially valuable strategies. This holistic approach applied to post conflict, if applied to understanding conflict, would strengthen the WPS agenda.

\section{Conceptual Framework: A Theoretical understanding of Conflict}

The WPS agenda is intended to protect women and girls in all conflict settings, but only focuses on those in settings in which conflict manifests itself as a particular form of violence. It follows that violence is an extreme visible result of conflict but not necessarily synonymous with conflict. The WPS agenda maps violence onto armed conflict scenarios. This understanding of conflict settings is plagued by a, "biased, universalising and stereotypical approach, focusing on the most visible practices and actors" (Santos, Moura, and Roque 2010, 3 ). Violence makes conflict visible, bringing to light physical, tangible harm and threat already within a society. However, due to the fact that the agenda highlights conflict as violence, this paper will use violence and conflict synonymously to broaden the critique on the understanding of conflict in the WPS agenda. This manifestation of conflict in violence has been further broken down by feminist scholars looking at how power functions. Arendt illustrates that this is not to say that power and violence are synonymous, but rather, "everything depends upon the power behind the violence" (17). That power is patriarchy.

Reardon (1985) furthers this argument by highlighting that there are gender hierarchies, and power structures present in our society which manifest themselves in times of war and peace. They have created a condition in which war has been masculinized, while peace is feminized. However, the masculinity of war is construed as, not just the manifestation of masculinity in its diversity, but rather as the manifestation of a specific form of masculinity, a hegemonic masculinity. It is important here to state that hegemonic masculinity is understood in the sense that Connell and Messerschmidt perceived it: Embodying, "the currently most honoured way of being a man, it required all other men to position themselves in relation to it, and it ideologically legitimated the global subordination of women to men" (Connell and Messerschmidt 2005, 832). 
In a conversation with Enloe, Cockburn remarks that although a combative and controlling masculinity is essential to war and conflict, "the patriarchal system of male dominance...gives rise to war-thinking and the war-habit" (Cockburn and Enloe 2012, 552). This is to say that conflict and violence are present, as long as the system of male dominance is present, however a focus on war highlights a singular form of masculinity as being the foundation of conflict. Conflict is thus not just a physical activity, but the presence of 'warthinking' and 'war-habits', which can manifest themselves in non-war settings. Feminists like Hunnicutt (2009) have argued that masculine and patriarchal 'war-thinking' is at the core of conflict and violence. Even within state structures, conflict and violence are experienced in gendered ways. This grows from the masculine nature of the state itself, such that any action that is nationalist or in favour of the state supports patriarchy. Boehmer (1992) argues that, "in its iconographies of power, nationalism may be characterised as a male drama" (233). Enloe (2000) has argued further that the traditional association of men and masculinity with war and violence is in itself a social construct. This means that war, violence, and conflict can exist even when masculinity presents itself differently in a particular context, which can happen in non-war zones.

While the aforementioned feminists and theorists are radical in how they apply a gendered lens to conflict and violence their major shortcoming is in foregrounding gender without looking at how there are other sites of oppression for different bodies in different contexts. Various postcolonial feminists (Nzegwu 2006; Parashar 2016) have looked at how race and histories of oppression can play out in understanding conflict and violence on an international scale, even within the context of international law. In an attempt to account for the gendered differences of violence encountered within postcolonial state structures, Parashar (2016) makes complex feminist theory by mapping it onto the postcolonial state. The postcolonial, in a spatial and temporal sense is defined, "as the act of resistance and overlooks the internal orthodoxies, injustices, silences, and marginalisations" (371). It is a complex space. Within postcolonial contexts, gender will thus function differently and applying a postcolonial lens to feminist theory offers the "conceptual tool box to see multiple sites of oppression and to reject universalism around gendered experiences of both men and women" (371). Within a postcolonial state, violence is engendered by the colonial history and the postcolonial state; it is embedded in all levels of social structures (Parashar 2016, 373). Thus, some violence and conflict may not manifest itself in generic universal ways, but it will still exist. While there is gendered violence in the structure of the nation state, Parashar extends the argument through a postcolonial state and says that "exclusion and violence is embedded in the very imaginary of the state in itself" (373). This means that in a postcolonial state, conflict can be the result of the state's very own function. Fanon echoes the same sentiments in his explanation of decolonisation. He writes that, "the violence which has ruled over the ordering of the colonial world...that same violence will be claimed and taken over by the native at the moment when, deciding to embody history in his own person, he surges into the forbidden quarters" (40). Thus, while a gendered lens is important to understand conflict and violence, there is likewise a need to bring in a postcolonial lens to analyse particular contexts and take into account the shortcoming of universalism within some feminists' arguments.

Ling (2013) offers a useful conceptual instrument that unites feminism and postcolonial thought to highlight the "ordinariness and the exceptionality of the multiple sites of violence in the world today"(373), in line with the nature of conflict in non-war zones. This theory is what Ling calls worldism, which is the result of social constructivism, postcolonial feminism, and dialectical International Relations relating closely. Ling's conceptualisation of worldism begins from the perspective of Daoist yin/yang dialectics. She writes that this is different from Hegelian-Marxian dialectics in which "conflict (opposition) accounts for the polarities and their transformation" (41). One of the key epistemological premises of Daoist dialectics is what Ling refers to as 'agency in context' (Ling 2013, 42). In the postcolonial context, "Daoist dialectics recognize the contrapuntalty between centres and peripheries, West and rest, Self and Other, to jointly produce the complicities that endure despite and sometimes 
because of the mutual conflicts that tear them apart" (Ling 2013, 45). Thus, from a Daoist dialectic perspective, conflict and violence need not only be understood in localised contexts and realities, but they also need to be understood in relation to the global context. This allows for an understanding of conflict that is unique to a country's history and socio-political reality, such as is the case in non-war zones. Ling's central contribution to using a Daoist dialectical approach to international relations is using gender-as-analytic. One of the goals of using gender-as-analytic is to focus "on the everyday as a site of redefinition and resistance" and "situating knowledge by theorizing from women's lived experiences" (Ling 2013, 57). These are areas from which we can truly read conflict and violence.

In her formulation of structures of equality, the African Feminist Philosopher Nkiru Nzegwu (2006) argues that under contemporary globalisation, the international community has sought to "homogenise the world under one value scheme" (201). Although Nzwegu's argument is based on an analysis of the modern African family in one specific area in Nigeria, her insights on the impact of international human rights discourse on gender equality in contemporary postcolonial African contexts is nonetheless essential to our considerations. She argues that the international framework that pushes for gender equality is a universalist one, the same one criticized by Ling. This framework upholds uniformity and in so doing it ignores that the idea of "rights and universality have cultural roots" whilst it treats them as "culturally neutral and absolute" (Nzegwu 2006, 202). If it can be argued that rights are not universalist, then the situations in which they are to be protected must not be viewed through a universalist lens either. This validates the conflict and abuses that occur in non-war zones. They should be seen and understood as specific to their context.

Kimberle Crenshaw (1991) has extensively considered this importance of the lived experience of violence and conflict, for groups in different contexts. Although Crenshaw writes in the context of African American women in the United States of America (USA), her analysis is relevant as she explores the location of race and gender dimensions in violence against women. Crenshaw argues that, "the violence that many women experience is often shaped by other dimensions of their identities, such as race and class" (1242). Women will not experience conflict and violence in similar ways, and a focus on just a gendered identity without attention to other facets of identity is a very limited lens through which one can look at women's experiences of conflict. While Crenshaw's study is located in shelters that protect and serve women who are victims of rape and battering, her insights are still useful as these women have suffered similar issues raised in the WPS agenda. She argues that the physical assault that these women suffer, "is merely the most immediate manifestation of the subordination they experience" (1245). Women's experiences of conflict and violence when limited to physical assault ignores and hides other potential markers of conflict and violence present within a community. Beyond that, it generalises and simplifies how different women experience conflict and violence and to what extent. This is because, "Women of colour are differently situated in the economic, social, and political worlds" (Crenshaw 1991, 1250). In opening up the understanding of violence to map it onto diverse groups there also rises a need to open it up to understanding different contexts. Similar considerations can be applied for postcolonial contexts.

$\underline{\text { Analysis }}$

Zimbabwe provides a rich framework in which to explore the issues of armed conflict in non-war zones. It also provides an important case-study in these ideas, one which highlights opportunities to augment the standard analysis with its urban, gun-violence based focus. It represents, in my view, an important case-study, arguing for the need to redefine conflict and violence. In Zimbabwe two traits of non-war zones stand out.

The first is that armed conflict and violence is centred around militarization and gender ideologies creating ordinariness of the violence (Santos, Moura, and Roque 2010, 5). In making a case for gender sensitive Security Sector Reform (SSR) in Zimbabwe, Mushonga (2016) argues that although Zimbabwe is not in a state of war, it has crucial insecurities. The biggest threat "to the security of women and girls is gender-based violence (GBV). According 
to the United Nations Population Fund (UNFPA), in Zimbabwe "1 in 3 women aged 15 to 49 have experienced physical violence and about 1 in 4 women have experienced sexual violence since the age of 15" ('Gender-Based Violence' 2016). The recognition of GBV as a consistent problem maps onto the trait of the ubiquitous, every day, violence and conflict in Zimbabwe and other non-war zones.

O'Gorman (2011) also has considered the militaristic nature of conflict in Zimbabwe. After two liberation wars, Zimbabwe gained its independence from Britain in 1980. This maps onto the trait of militarisation. Although focused on extrapolating from Zimbabwe's experience with the anti-colonial liberation struggle, her historical grounding contextualises how and why Zimbabwe is a non-war zone in contemporary time, arguing that, "the legacies of revolutionary wars and the manner in which they were fought have produced legacy dynamics that inform continuing struggles of legitimacy, authority and power in post-colonial states" (3). Here I must point that, while this is an important observation it can be read as othering postcolonial nations by assigning primary responsibility for post-colonial instabilities to the just fight against colonialism, and not rooting current instabilities in the history of colonialism. Furthermore, western colonial nations today are facing struggles of legitimacy and authority although they are not postcolonial nations such as Brexit.

The second characteristic of non-war zones in the case of Zimbabwe, is that which Santos and others referred to as 'formal peace'. Gorman argues that in the absence of the political realities of past war and Zimbabwe's role in some peacekeeping missions, one can get the impression that "Zimbabwe itself is in a different place"(2). This 'different impression', is that by standard measures, Zimbabwe is not a country in war, but rather a nation in formal peace. I focus on Zimbabwe from 2000 to 2019. Prior to September 1999, Zimbabwe was essentially a one party state (Raftopoulos and Mlambo 2009, 209). From late 1999, the state allowed greater democratic and civil society activity, and an attempt to model of most 'stable' nations around the globe.

Zimbabwe also extends the understanding of non-war zones, from Santos and others' focus. Zimbabwe has the presence of armed violence, but it goes beyond urban areas. Gorman attests to this in her description of Zimbabwe. She mentions that "two particular groups have emerged as critical to political control, particularly on the rural areas: the war veterans and the youth militia"(5). One might expect that Zimbabwe has a NAP, in line with the WPS agenda, to address this conflict. But I argue that, due to the narrow understanding of conflict, operationalising the WPS agenda can be seen to be a secondary concern.

Zimbabwe, although not exhibiting signs of what the WPS agenda considers conflict, is a country that has been in conflict for a while. Using Zimbabwe as an example, it becomes clear that the understanding of conflict in the WPS agenda must be broadened if women, girls, children, and othered men are to be protected in times of conflict. I argue that the case of Zimbabwe, a non-war zone, highlights the need for a broader understanding of conflict as it exhibits the presence of war thinking as articulated by Reardon (1985) while presenting a clear case of two parties at conflict; the state versus the people. This relationship centred on conflict between civilians and the state security forces was established during the colonial era (Fanon 1967, 38). This results in the experiences of women, girls, children, and othered men being side-lined. Beginning in 2000, there are three particular moments through which the conflict in Zimbabwe can be exemplified: the fast track land reform, the electoral moments, and the day to day experiences under the so-called new dispensation. These three periods exemplify and expand the concept of non-war zone in conflict.

\section{The Fast Track Land Reform Program (FTLRP)}

The war mentality that was present during the country's liberation struggles has continued to haunt the country post-independence, keeping it in a state of conflict. Kriger $(2003,14)$ says that this is because the ruling party, Zimbabwe African National Union Patriotic Front (ZANU-PF), used war veterans post-independence "to build power in the army, the bureaucracy, and among urban workers... it used veterans alongside others, and especially youth, to try to preserve its power among these constituencies," beginning 2000 (139). This is 
the first sign of the war-thinking that Reardon argues upholds a war system (11). In 2000, war veterans in Zimbabwe became active in support of the then-president's land reform program. The government drew on the "long post-colonial relationship of collaboration and conflict between the state and war veterans" (Raftopoulos and Mlambo 2009, 211) and embarked on a process of violent land occupations.

Zimbabwe, like many other African states, inherited racist colonial land distribution models at independence in which the colonial white minority had majority of the commercial arable land (Mafa, Gudhlanga, and Manyeruke 2015, 65). From 26 February 2000, with the support of ZANU-PF, "war veterans, peasants and youths invaded white owned farms throughout the country" (Mafa, Gudhlanga, and Manyeruke 2015, 96). The process turned militant, violent and combative as participants reverted to the war thinking that was present during the liberation struggle. This war thinking was grounded in the belief that the only way to a politically just system of land distribution was through physical violence, and that only those who have either historically partaken of war or are presently engaged in this war for land, deserve it.

Here it is important to recall Parashar's observation, that conflict in the postcolonial state is a part of the colonial history (Parashar, 2016), and as Fanon articulated, in a bid to become free of that history, one then turns to that same violence (Fanon, 1967). The land in question was stolen through imperialist violence. Thus, one can say that that legacy of violent land conflict, did not begin with the liberation struggle, it simply continued in this particular moment. Even 'born-frees', those born after independence, would tout the liberation history of Zimbabwe and the need to take up arms against white settlers that owned most of the land (Mutanda, 2013)

The conflict in Zimbabwe during the FTLRP, was gendered in both driving forces and effects. It was majority male war veterans and youth who enacted the violence on farmers and their workers. Reardon's analysis of the patriarchal nature of our societies being the basis on which conflict and violence are built is essential when applying a gendered lens to the fast track land reform. Land and property ownership in Zimbabwe is patriarchal. In their study of gender and land politics in Zimbabwe, Mafa and others note that, "men are always considered to be the head of the family and land is allocated to the head of the family who is presumed to be male. This means that women's access to resources like land is limited" (Mafa, Gudhlanga, and Manyeruke 2015, 113). In female headed households, access to land was limited by gender hierarchies, even though some women fought in the liberation struggle and were thus war veterans. Zimbabwean women were therefore oppressed and silenced in a conflict setting as it was mostly men that were entitled to land ownership. The patriarchal system blocking women from accessing land led to the feminisation of poverty in rural areas (Mafa, Gudhlanga, and Manyeruke 2015, 113). Women thus faced the brunt of the effects of this land conflict. This should be considered violence as it was created by a state of conflict. Beyond that, it is violence because it leads to other forms of subordination that are also very gendered. Moyo (2004) argues that, "Women farm workers were at any rate the most vulnerable group before the FTLRP and, since they were the majority doing casual work (constituted 55\% of the casual labourers in 2000), they performed arduous piecework and were least the represented among skilled workers" (Moyo 2004, 26).

Not all women were side-lined in the land reform program. As Crenshaw acknowledges, women will experience violence, and consequently conflict, differently based on other factors such as class and race (Crenshaw 1991). It was not only race, since Black people worked the white-owned farms in Zimbabwe, but also class that compounded the violence that women faced in this conflict. Matondi (2012) writes that in a rural district called Mazowe, "women were the last beneficiaries, after men were satisfied with their choice of plots and 'ordinary' women were always at the end of the queue in the allocations and other benefits" (Matondi 2012, 185). In that same district, in coming years, Grace Mugabe, the former first lady, seized a large piece of land to herself (Sengupta 2017). The violence that some women suffered in this conflict was not only because they were women, but it was 
because they were women of what would be considered a lower class. The WPS agenda with its focus on war-violence would not recognise this as conflict although this subordination is the bedrock of the war violence that the agenda focuses on. For example, while it is important that UNSCR 1820 recognises sexual violence a weapon of war, the neglect by other resolutions to look at other non-sexual forms of violence ignores conflict in a non-war zone.

Through Enloe's (Cockburn and Enloe 2012) lens on the how hegemonic masculinities are associated with violence, a similar analysis can be used to reveal victims of conflict in Zimbabwe that would need to be acknowledged by the WPS agenda. One can argue that male and female war veterans, who are former soldiers and have yielded arms are representative of the hegemonic masculinity that drives forth violence and conflict. Other men were, together with women, victims of this conflict. The Daily News, a Zimbabwean newspaper, followed up on victims of the FTLRP in 2014 and reported on a 38-year-old man named Samuel Makazu (Chikwanha 2014) . Makazu became destitute after the farm he used to work on was claimed by violent war veterans. His problem was compounded by the fact that he was a firstgeneration immigrant farm worker and had no home to return to. Through both; the story of Makazu and the feminisation of poverty as a result of the fast track land reform, a case can be made that this was indeed a conflict as there was the oppression of certain groups by others. Beyond that, the case fits a non-war zone perfectly in that it was supported by deep war thinking and presented armed violence as some war veterans yielded arms. The moment of the FTLRP also expands on non-war zones by taking the site of conflict to the farm areas, for although urban youth were involved as perpetrators, the location for this conflict was not just urban areas that Santos and others focus on.

\section{The Electoral Moment}

The formation of an opposition party, the then Movement for Democratic Change (MDC), threatened ZANU-PF. Beginning with the general elections in 2000 and the presidential elections in 2002, "the MDC and its supporters were subjected to widespread violence - murder, attempted murder, torture, rape, disappearances and death threats - much of it carried out by the ruling party's youth militia group" (Raftopoulos and Mlambo 2009, 215). The conflict manifested itself in the same way that the WPS agenda expects conflict to occur. The major difference however was that the driver of conflict was a state sanctioned body. The WPS agenda places the responsibility to protect civilians and to train military personnel on government as seen through UNSCR 1888 (2009) and 1820 (2008) discussed above. This ignores the reality in Zimbabwe, where the driver of conflict is the state and the responsibility to protect is neglected.

It is important here to recall that the other weakness of the understanding of conflict in the WPS agenda, is on how men are poised as perpetrators of violence. The electoral moment in Zimbabwe illustrates that although militia men were perpetrators of violence, othered men fell victim to that violence. In the 2008 elections, numerous men in rural areas were also victims of electoral violence. A report by Human Rights Watch highlighted this conflict. An example is that, "on May 5 in Chiweshe, ZANU- PF officials and "war veterans" beat six men to death" while on the $10^{\text {th }}$ of April "ZANU-PF supporters brutally beat about 20 men suspected of voting for the MDC before the entire village" (Kasambala 2008). Men, who when marginalised can also be victims in very physical ways, are not consistently represented in the WPS agenda's understanding of conflict. Thus, these politically motivated, yet state sanctioned muggings and deaths would not fall under conflict scenarios.

Cockburn and Enloe have gone beyond acknowledging the deep-seated nature of patriarchy in society and analysed how the nation state is itself comparative to a hyper masculine organism(Cockburn and Enloe 2012). The silencing of men by other men with more power in that moment, through state sanctioned violence, points to this. Through Reardon's exploration of the patriarchal oppressive war system, the case of Zimbabwean electoral violence then highlights that Zimbabwe although not at war, was in this moment in a conflict founded on a war system. Women and othered men who were publicly beaten bore the brunt 
of the violence in this conflict, and by the aims of the WPS agenda, they too should have been protected.

The ways in which Zimbabwean women were severely affected by the electoral conflict and violence is present in other ways that the WPS agenda does not recognise. The state, as a patriarchal body, created economic conflict and excluded women, girls, othered men and children in the process. As the Zimbabwean economy went into decline in the early 2000s, many Zimbabweans moved into the informal sector. According to the ILO, as of 2004, 80.7\% of jobs in Zimbabwe had been informalized and of the population in the informal sector, $53 \%$ were women (Joint Programme on Gender Equality 2018). In May of 2005, the government carried out Operation Murambatsvina, a "militarised urban clean-up" in which the security forces and youth militia monitored the destruction of 'informal' structures in urban areas (Raftopoulos and Mlambo 2009, 220). Most of these structures either served as homes to poorer women and children or they served as marketplaces for vending women and men in the informal sector. Very often they served as both. This particular event drags conflict back into the urban areas studied by Santos and others (Santos, Moura, and Roque 2010) A UN report on the operation noted that, "Already socially and economically disadvantaged, many women and girls have suffered greatly and been rendered more vulnerable through the sudden loss of homes and livelihoods. Single mothers, widows and mothers with sick or disabled children have been put in a particularly difficult situation" (Tibaijuka 2005, 43). Here is yet another instance in which the masculine state oppresses women and othered men in an unrecognized conflict. A better understanding of this conflict and its effect is seen through the application of Ling's idea of contrapuntalty, that the individual is part of a global system (Ling 2013, 45). One of the reasons for the economic decline was the western economic recommendations to impose an Economic Structural Adjustment Plan (ESAP) in the early 1990s (Weaving 1996). Here Zimbabwe's interaction with the global economic system becomes the foundation of ripe conditions for conflict in the country. Furthermore, ZANU-PF's reason for embarking on this operation was to weaken urban areas that were becoming a stronghold of the opposition MDC ahead of elections (Raftopoulos and Mlambo 2009, 221). This was in fact part of electoral violence. Those that suffered the violence were subjects of arbitrary political violence which aimed at serving a larger system. However, as Arendt (1969) observes, violence is never successful in achieving the desired aim. As seen in Zimbabwe, the conflict between the state and the people has not ended and the desired end has not been achieved.

\section{The 'New Dispensation'}

Another moment in Zimbabwe's most recent history showing the presence of conflict in a non-war zone is the period of time beginning with the military takeover in November 2017 to present. On the $15^{\text {th }}$ of November 2017, then Major General Sibusiso Moyo appeared on live television at around 4am announcing that the then president of Zimbabwe was safe, and what the country was experiencing a peaceful military takeover, not a coup (Zim Stones 2017). This was the beginning of the next two days with army tanks in the streets, civilians marching, and the eventual resignation of Robert Mugabe. There was no publicized bloodshed, signature of a coup. Many of the images emerging from this moment show civilians and soldiers in harmony. Yet, I argue, this was still a moment of conflict.

In the case of the Zimbabwean military takeover, it was the exhibition of a different form of hegemonic masculinity that is not recognized by the WPS agenda's understanding of violence that masked the conflict that was present in the moment. As highlighted previously, the WPS agenda recognizes the hegemonic militarized masculinity as it manifests in violent conflict settings. It was not until UNSCR 2100 that there was a recognition that men too can be victims of sexual violence and even then, it was in subjection to a specific form of violent armed masculinity. What Zimbabwe's military takeover shows is that a hegemonic masculinity can manifest itself non-violently in times of conflict in non-war zones.

By November 2017 'peaceful' men in military gear were a permanent fixture on the streets of Harare; it should have become clear that this was a moment of conflict. The lives of citizens were affected as roadblocks were no longer set by the traffic police whose 
constitutional duty it is to keep the roads safe, but by army officers. This failure to name this a moment of conflict is a result of what Ling recognises as the universalist nature of international organisations in their bid to homogenise nations (Ling 2013, 57). The WPS agenda is, from the UNSC perspective, the pinnacle of western governance. Its perspective on conflict is thus only based on what the nations in the Security Council would perceive as conflict in nonwestern nations. In her post-colonial critique of UNSCR 1325 (2000), Pratt argues that in UNSCR1325 the "reconceptualization of gender occurs through a re-inscription of racialsexual boundaries, evocative of the political economy of imperialism" (Pratt 2013, 772). She points to the western imperial perspective that taints how the resolution addresses certain issues. It thus can be extended to how conflict is addressed by the entire WPS agenda, that there is a deep-rooted racialized notion of how masculinities and femininities will manifest in times of conflict. Thus, when in some non-war zones, such as Zimbabwe, hegemonic masculinities are not visibly violent there is a hesitation to call it a conflict

It is important that I return to the point that the WPS agenda conflates conflict and violence. The WPS agenda's focuses on violence as a signifier of conflict is what presents a racialized understanding of how conflict manifests itself. From the beginning of the military takeover, violence was always threatened. In his address, Moyo said, "What the Zimbabwe Defence Forces is doing is to pacify a degenerating political, social, and economic situation in our country which if not addressed may result in violent conflict [emphasis added]" (Zim Stones 2017). However, the country was already in conflict, albeit not a violent one. Conflict is when there is a system of dominance and subordination and in order to see that play out in this particular case, one can look to Mbembe (2001). He argues that in a postcolonial state, particularly in Africa, in order to understand domination and subordination and recognize the patterns of power, one must turn to the visual imagery and discourse. The presence of a man, Moyo, clad in military uniform on national television, in the early hours of the morning, declared the power of the military as an institution over every other civilian in the state. There was no need for physical violence to ascertain this power, the tanks in the streets and men with guns in the city spoke for themselves.

The WPS agenda does not make provisions for non-violent conflict such as this, conflict which is most likely to manifest in non-war zones. It would be naïve, however, to state this moment completely free of violence. There were videos circulating on social media of a soldier in uniform slapping a civilian woman on the evening of that solidarity march (Mari 2017). This shows that there were incidents of physical violence but because they were not many and typical of conflict, the scenario would not be considered conflict. In another instance, the conflict in Zimbabwe took off its non-war zone mask on the $1^{\text {st }}$ of August in 2018 when the military shot six civilians during peaceful protests in the central business district (Fihlani 2018).

This violence by the state in the postcolonial context is the result of the war thinking that created the modern postcolonial state and it is this war thinking that will likely sustain them in their current form. Under the so-called new dispensation, the conflict in Zimbabwe has now reached new levels and is beginning to manifest itself in ways that some resolutions of the WPS agenda recognise - largely because conflict is now being expressed through more visible physical violence. However, Zimbabwe still does not have a WPS National Action Plan (NAP) as recommended by the agenda. The narrow nature of the understanding of conflict makes it difficult for civil society to rally around a cause and make the case to operationalise the WPS Agenda in the Zimbabwean context.

\section{Conclusion}

I began with the question, "How does the case of Zimbabwe as a non-war zone in conflict, exemplify the need for a broader understanding of conflict in the WPS agenda?" I then reviewed literature on non-war zones noting the strengths and gaps in the work from which this term is drawn thus adding to that discussion and expanding on the nature of nonwar zones. I applied a Feminist Post Structural Discourse Analysis to the WPS resolutions and critical theory through feminist and post-colonial lenses to the case of Zimbabwe. 
The WPS agenda was without a doubt a ground-breaking agenda. Until the first resolution in 2000, there had been many cases in which women, in particular, were oppressed and silenced in conflict areas. There are many more cases in which women, children, and othered men are also erased in conflict. The case of Zimbabwe exemplifies the need for a broader understanding of conflict in the WPS agenda.

A case- study of recent Zimbabwean history, exemplifies how a non-war zone in conflict highlights the need for the WPS agenda to broaden its understanding of conflict to include contexts in which armed violence manifests itself differently from war zones. This is essential so that recommendations for the protection of women, children, and othered men can be made for a more diverse set of nations. Additionally, if the WPS agenda is to broaden how it defines conflict more nations will be able to effectively operationalise the agenda through the creation of NAPs that are context specific, supported and led by local civil society organisations.

The use of theoretical analysis makes this study applicable in more contexts than Zimbabwe. Looking at non war zones, one can then consider how other nations and organisations can create NAPs that are more specific to their context. This call to action is also pertinent to countries, in particular Western countries, which have NAPs that focus only on their peacekeeping missions. They can begin to reconsider how conflict plays out within their context and how women, children, and othered men can be protected. For example we can consider the death of black people at the hands of police in the USA a conflict (Khazan 2018). How can we protect vulnerable demographics in geographies that are not at war, but which are in conflict? Can we begin to look at the scores of Missing and Murdered Indigenous Women and Girls (MMIWG) in Canada as a conflict scenario? This paper does not attempt to answer all those questions or claim to provide all the answers, but it simply seeks to add to a conversation on redefining conflict, while beginning a conversation on expanding the WPS agenda.

\section{Bibliography}

Arendt, Hannah. 1969. 'Reflections on Violence'. Journal of International Affairs 23 (1): 135.

Baxter, Judith. 2003. Positioning Gender in Discourse - A Feminist Methodology. 1st ed. Palgrave Macmillan UK. https://www.palgrave.com/gp/book/9780333986356.

Boehmer, Elleke. 1992. 'Motherlands, Mothers and Nationalist Sons: Representations of Nationalism and Women in African Literature'. In From Commonwealth to PostColonial, edited by Anna Rutherford. Sydney : Dangaroo Press. https://trove.nla.gov.au/version/43581515.

Cabrera-Balleza, Mavic. 2011. 'It Is Time to Walk the Talk and Fulfill the Promise of UNSCR 1325'. Palestine - Israel Journal of Politics, Economics, and Culture 17 (3/4): 16-24.

Chikwanha, Thelma. 2014. 'Land Seizures Leave Farm Workers Destitute'. DailyNews Live, 4 May 2014. https://www.dailynews.co.zw/articles/2014/05/04/land-seizures-leavefarm-workers-destitute.

Chinkin, Christine, and Mary Kaldor. 2013. 'Gender and New Wars'. Journal of International Affairs 67 (1): 167-87.

Cockburn, Cynthia, and Cynthia Enloe. 2012. 'Militarism, Patriarchy and Peace Movements'. International Feminist Journal of Politics 14 (4): 550-57. https://doi.org/10.1080/14616742.2012.726098.

Connell, R. W., and James W. Messerschmidt. 2005. 'Hegemonic Masculinity: Rethinking the Concept'. Gender \& Society 19 (6): 829-59. https://doi.org/10.1177/0891243205278639.

Crenshaw, Kimberle. 1991. 'Mapping the Margins: Intersectionality, Identity Politics, and Violence against Women of Color'. Stanford Law Review 43 (6): 1241-99. https://doi.org/10.2307/1229039. 
Enloe, Cynthia. 2000. Maneuvers: The International Politics of Militarizing Women's Lives. First edition. Berkeley: University of California Press.

Fanon, Frantz. 1967. The Wretched of the Earth. Translated By Constance Farrington. Preface by Jean-Paul Sartre. First Pr. Thus edition. Penguin.

Fihlani, Pumza. 2018. 'Deadly Poll Violence in Zimbabwe Capital'. BBC News, 1 August 2018, sec. Africa. https://www.bbc.com/news/world-africa-45035533.

Frazer, Jessica. 2010. 'Gendering the Agenda - Discursive Constructions of Gender within the Security Council's "Women, Peace and Security" Agenda', January. https://ses.library.usyd.edu.au/handle/2123/8341.

'Gender-Based Violence'. 2016. UNFPA Zimbabwe. 8 February 2016. https://zimbabwe.unfpa.org/en/topics/gender-based-violence-0.

Haastrup, Toni. 2018. 'Creating Cinderella? The Unintended Consequences of the Women Peace and Security Agenda for EU's Mediation Architecture'. International Negotiation 23 (2): 218-37. https://doi.org/10.1163/15718069-23021150.

Hunnicutt, Gwen. 2009. 'Varieties of Patriarchy and Violence Against Women: Resurrecting "Patriarchy" as a Theoretical Tool'. Violence Against Women 15 (5): 553-73. https://doi.org/10.1177/1077801208331246.

Joint Programme on Gender Equality. 2018. 'Women in the Informal Economy in Zimbabwe - Situational Analysis'. Publication. http://www.ilo.org/africa/countriescovered/zimbabwe/WCMS_619740/lang--en/index.htm.

Kasambala, Tiseke. 2008. "“Bullets for Each of You”| State-Sponsored Violence since Zimbabwe's March 29 Elections'. Human Rights Watch. https://www.hrw.org/report/2008/06/09/bullets-each-you/state-sponsored-violencezimbabwes-march-29-elections.

Khazan, Olga. 2018. 'In One Year, 57,375 Years of Life Were Lost to Police Violence'. The Atlantic, 8 May 2018. https://www.theatlantic.com/health/archive/2018/05/the-57375years-of-life-lost-to-police-violence/559835/.

Kriger, Norma. 2003. 'War Veterans: Continuities between the Past and the Present'. African Studies Quarterly 7 (January).

Ling, L. H. M. 2013. The Dao of World Politics. 1 edition. London; New York: Routledge.

Mafa, Onias, Enna S. Gudhlanga, and Norman Manyeruke. 2015. Gender, Politics and Land Use in Zimbabwe 1980-2012. Dakar Senegal: Codesria.

Malone, David M. 2008. 'Security Council'. The Oxford Handbook on the United Nations, November. https://doi.org/10.1093/oxfordhb/9780199560103.003.0006.

Mari, Adam. 2017. Zimbabwean Soldier Slaps a Woman in the Streets of Harare. https://www.youtube.com/watch?v=GhPHhXGuhAc.

Matondi, Prosper B. 2012. Zimbabwe's Fast Track Land Reform. 1 edition. Zed Books.

Miller, Barbara, Milad Pournik, and Aisling Swaine. 2014. 'Women in Peace and Security through United Nations Security Resolution 1325: Literature Review, Content Analysis of National Action Plans, and Implementation'. Institute for Global and International Studies George Washington University. https://gsdrc.org/documentlibrary/women-in-peace-and-security-through-united-nations-security-resolution1325-literature-review-content-analysis-of-national-action-plans-andimplementation/.

Moura, Tatiana, and Sílvia Roque. 2009. 'Invisible Vulnerabilities The Cases of Rio de Jeneiro (Brazil) and San Salvador (El Savador)'. In Cities and Crises, edited by Dennis Day, Annette Grindsted, Brigitte Piquard, and David Zammit. Universidad de Deusto.

Moyo, Sam. 2004. 'Overall Impacts of Fast Track Land Reform Programme', January. Mushonga, Netsai. 2016. 'A Case Study of Gender and Security Sector Reform in Zimbabwe'. In Gender, Peace and Security in Africa, edited by Cheryl Hendricks and Romi Sigsworth, 1 edition. S.1.: Routledge. 
Mutanda, Darlington. 2013. 'The Politicisation, Dynamics and Violence during Zimbabwe's Land Reform Programme'. Journal of Aggression, Conflict and Peace Research, January. https://doi.org/10.1108/17596591311290731.

Ní Aoláin, Fionnuala. 2016. 'The "War on Terror" and Extremism: Assessing the Relevance of the Women, Peace and Security Agenda'. International Affairs 92 (2): 275-91. https://doi.org/10.1111/1468-2346.12552.

Nzegwu, Nkiru Uwechia. 2006. Family Matters: Feminist Concepts in African Philosophy of Culture. Annotated edition. Albany: State Univ of New York Pr.

O'Gorman, Eleanor. 2011. The Front Line Runs Through Every Woman: Women \& Local Resistance in the Zimbabwean Liberation War. Boydell \& Brewer Ltd.

Parashar, Swati. 2016. 'Feminism and Postcolonialism: (En)Gendering Encounters'. Postcolonial Studies 19 (4): 371-77. https://doi.org/10.1080/13688790.2016.1317388.

Peace Women. 2014. 'Solutions: Innovative WPS Agenda'. PeaceWomen. 28 November 2014. https://www.peacewomen.org/why-WPS/solutions.

Pratt, Nicola. 2013. 'Reconceptualizing Gender, Reinscribing Racial-Sexual Boundaries in International Security: The Case of UN Security Council Resolution 1325 on "Women, Peace and Security"'. International Studies Quarterly 57 (4): 772-83. https://doi.org/10.1111/isqu.12032.

Raftopoulos, Brian, and Alois Mlambo, eds. 2009. Becoming Zimbabwe. A History from the Pre-Colonial Period to 2008. Harare: Weaver Press.

Reardon, Betty. 1985. Sexism and the War System. Teachers College Press.

Santos, Rita, Tatiana Moura, and Sílvia Roque. 2010. 'UNSCR 1325: Is It Only about War? Armed Violence in Non-War Contexts'. Working Paper. Centro de Estudos Sociais. https://estudogeral.sib.uc.pt/handle/10316/32668.

Scheper-Hughes, Nancy. 1997. 'Specificities: Peace-Time Crimes'. Social Identities 3 (3): 471-98. https://doi.org/10.1080/13504639752014.

Sengupta, Kim. 2017. 'How Grace Mugabe Seized Farmers' Land for Opulent Mansion in "Graceland" While They Slept Hungry under Trees'. The Independent, 26 November 2017, sec. World. http://www.independent.co.uk/news/world/africa/mazowe-fortressgraceland-zimbabwe-robert-mugabe-emmerson-mnangagwa-a8076971.html.

Smith, Elizabeth Seymour. 2020. 'Climate Change in Women, Peace and Security National Action Plans'. Stockholm International Peace Research Institute. JSTOR. https://doi.org/10.2307/resrep25311.

'S/RES/1325 : UN Documents : Security Council Report'. 2000. 2000. https://www.securitycouncilreport.org/un-documents/document/wps-sres1325.php.

'S/RES/1820 : UN Documents : Security Council Report'. 2008. 2008. https://www.securitycouncilreport.org/un-documents/document/cac-s-res-1820.php.

'S/RES/1888 : UN Documents : Security Council Report'. 2009. 2009. https://www.securitycouncilreport.org/un-documents/document/wps-sres-1888.php.

'S/RES/1889 : UN Documents : Security Council Report'. 2009. 2009. https://www.securitycouncilreport.org/un-documents/document/wps-sres-1889.php.

'S/RES/2106 : UN Documents : Security Council Report'. 2013. 2013. https://www.securitycouncilreport.org/un-documents/document/sres2106.php.

'S/RES/2122 : UN Documents : Security Council Report'. 2013. 2013. https://www.securitycouncilreport.org/un-documents/document/sres2122.php.

'S/RES/2467 : UN Documents : Security Council Report'. 2019. 2019. https://www.securitycouncilreport.org/un-documents/document/s-res-2467.php.

Tibaijuka, Anna Kajumulo. 2005. 'Report of the Fact-Finding Mission to Zimbabwe to Assess the Scope and Impact of Operation Murambatsvina'. Harare: Environment \& Urbanization. https://www.environmentandurbanization.org/report-fact-findingmission-zimbabwe-assess-scope-and-impact-operation-murambatsvina. 
True, Jacqui. 2010. 'Feminism and Gender Studies in International Relations Theory'. Oxford Research Encyclopedia of International Studies, March. https://doi.org/10.1093/acrefore/9780190846626.013.46.

Weaving, Rachel V. 1996. 'Structural Adjustment and Zimbabwe's Poor'. 28674. The World Bank. http://documents.worldbank.org/curated/en/189141468782142997/Structuraladjustment-and-Zimbabwes-poor.

Weedon, Chris. 1987. Feminist Practice and Poststructuralist Theory. Oxford, UK ; New York, NY, USA: B. Blackwell.

Women's International League for Peace and Freedom. 2014. 'Member States'. PeaceWomen. 14 November 2014. https://www.peacewomen.org/member-states.

Zim Stones. 2017. FULL Zim Army Statement Maj Gen SB Moyo Subtitles Statement in Description Box. https://www.youtube.com/watch?v=ubmKTLeJZLU. 